Article

\title{
"Technology Readiness and Acceptance Model" as a Predictor for the Use Intention of Data Standards in Smart Cities
}

\author{
Raf Buyle ${ }^{1, *}$, Mathias Van Compernolle ${ }^{2}$, Eveline Vlassenroot ${ }^{2}$, Ziggy Vanlishout ${ }^{3}$, Peter Mechant ${ }^{2}$ \\ and Erik Mannens ${ }^{1}$ \\ ${ }^{1}$ Internet Technology and Data Science Lab, Ghent University, 9000 Ghent, Belgium; E-Mails: raf.buyle@ugent.be (R.B.), \\ erik.mannens@ugent.be (E.M.) \\ 2 Research Group for Media, Innovation, and Communication Technologies, Ghent University, 9000 Ghent, Belgium; \\ E-Mails: mathias.vancompernolle@ugent.be (M.V.C.), eveline.vlassenroot@ugent.be (E.V.), peter.mechant@ugent.be (P.M.) \\ 3 Informatie Vlaanderen, Flemish Government, 1000 Brussels, Belgium; E-Mail: siegfried.vanlishout@kb.vlaanderen.be \\ * Corresponding author
}

Submitted: 6 July 2018 | Accepted: 26 November 2018 | Published: 21 December 2018

\begin{abstract}
Taking the region of Flanders in Belgium as a case study, this article reflects on how smart cities initiated a grassroots initiative on data interoperability. We observe that cities are struggling due to the fragmentation of data and services across different governmental levels. This may cause frustrations in the everyday life of citizens as they expect a coherent user experience. Our research question considers the relationship between individual characteristics of decision makers and their intention to use data standards. We identified criteria for implementing data standards in the public sector by analysing the factors that affect the adoption of data governance, based on the Technology Readiness and Acceptance Model (TRAM), by conducting an online survey $(n=205)$. Results indicate that respondents who score high on innovativeness have a higher intention to use data standards. However, we conclude that personality characteristics as described in the TRAM-model are not significant predictors of the perceived usefulness and perceived ease of use of data standards. Therefore, we suggest exploring the effects of network governance and organisational impediments to speed-up the adoption of open standards and raise interoperability in complex ecosystems.
\end{abstract}

\section{Keywords}

data governance; decentralisation; e-government; interoperability; linked data; policy making; smart cities; TRAM; standardisation

\section{Issue}

This article is part of the issue "E-Government and Smart Cities: Theoretical Reflections and Case Studies", edited by Peter Mechant (Ghent University, Belgium) and Nils Walravens (Vrije Universiteit Brussel, Belgium).

(C) 2018 by the authors; licensee Cogitatio (Lisbon, Portugal). This article is licensed under a Creative Commons Attribution 4.0 International License (CC BY).

\section{Introduction}

\subsection{Data Standards}

Flemish municipalities provide over 800 public services in domains such as building permits, subsidies, public welfare, and day-care. The back-office processes and service delivery of these services are supported by specialised information systems (IS) from different software vendors (Buyle, 2017). Because the data in these IS is modelled from a single thematic perspective, it is difficult or impossible to share and reuse them across all services (Davies, Harris, Crichton, Shukla, \& Gibbons, 2008). This causes unnecessary frustrations in the everyday life of citizens and businesses as they are required to repeatedly provide the same information to their government (European Commission, 2014). The smart use of citizens' information by public administrations is referred to as the once-only principle (European Commission, 2014). Also, the transformation of society towards a digital econ- 
omy is leading to changing roles as well as the blurring of the boundaries between public and private actors (European Commission, 2013). This is occurring in a context where information and IS are being combined with new technologies such as live data from physical devices (Viale Pereira, Cunha, Lampoltshammer, Parycek, \& Testa, 2017). Smart cities have a comprehensive commitment to innovation in technology, management, and policy according to Nam and Pardo (2011). In 2012 Flemish cities started a grassroots initiative to overcome this fragmented data landscape and implement 'onceonly' via the Open Standards for Linked Organisations programme (OSLO). The initiative was launched as a private-public partnership in the region of Flanders in Belgium, co-funded by the cities, the regional government of Flanders, and Information and Communication Technology (ICT) service suppliers (Buyle et al., 2016). The goal of OSLO is to raise interoperability in the region of Flanders. Interoperability is the ability of organisations to share information and knowledge, through the business processes they support, by exchanging data between their ICT systems (European Commission, 2017).

For centuries, standards have been fueling innovation, catalysing the growth of markets, and protecting the health and safety of citizens (Mills, 2013). In the sixteenth century, nuts and bolts were hand-crafted in matching pairs. In 1800, Henry Maudslay invented the screw-cutting lathe, which allowed screws to be produced with standardised thread (Roe, 1916). As they became interchangeable, it was possible to create interchangeable machine parts which enabled the Industrial Revolution. This turning point can be compared to the invention of the World Wide Web by Tim Berners Lee. Just as any nut and bolt adhering to the standards can be combined, electronic documents formatted in HyperText Markup Language (HTML) and transferred using the (Hypertext Transfer Protocol) HTTP can be exchanged via the Web (Sheridan, 2010). This created a digital revolution with new forms for social and economic enterprise as well as a new scope and greater efficiency for markets (Brynjolfsson \& Kahin, 2000). The safety of citizens is often a driver for standardisation. On July 30th, 2004, an immense explosion took place in the city of Ghislenghien in Belgium. The blast, with a radius of $6 \mathrm{~km}$, killed 24 people instantly and injured over 232 others. The disaster was caused by the leakage of a high-pressure gas pipe which had been damaged by a drilling machine (De Soir et al., 2015). Following this incident, the Flemish Government agreed on a common standard for exchanging information on cables and pipes and a single-point-ofaccess was established to automate the process to provide utility data in support of groundworks (Vlaams Parlement, 2008). This standardisation process resulted in a reduction of claims and incidents, and in significant time and financial savings (Lieberman \& Ryan, 2017).

The literature differentiates between de jure and de facto standards (Farrell \& Simcoe, 1996; Funk, 2001). De facto standards refer to processes whose objective is uni- formity, where all or nearly all potential adopters use the same interoperability agreements and turn it into a system that is hard to deviate from (Brunsson, Rasche, \& Seidl, 2012), such as the native Microsoft Word 'doc' and 'docx' file format for storing and exchanging text documents. By contrast, de jure standards are those which emerge through consensus. Consensus may be reached informally or formally expressed through an industry standards body or by a standards organisation such as the International Organization for Standardization (Stango, 2004). EU-Regulation No 1025/2012 (European Union, 2012, pp. 316-319) defines a 'standard' as "a technical specification, adopted by a recognised standardisation body, for repeated or continuous application".

Most standard setting organisations promote the adoption of Open Standards (Simcoe, 2006). Although the precise meaning of "open" in the context of data standards is highly debated and contested (Chesbrough, Vanhaverbeke, \& West, 2006), the term “open" refers both to the availability of specifications as well as the openness of the development process itself (Open Stand, 2012).

\subsection{A Historical Perspective of Standardisation Initiatives in Flanders}

Belgium is a federal country with three communities, three regions, and four language areas. Flanders is the northern federal state of Belgium with over 6 million inhabitants, or about $60 \%$ of the population, covering an area of $13,522 \mathrm{~km}^{2}$. According to Steen and Wayenberg (2003), the complex state structure is reflected in the organisation of local government. Just 12 cities have more than 50,000 citizens whereas $30 \%$ of cities have less than 10,000 citizens. As the number of public servants in the cities varies from 1 in the municipality of Herstappe up to 6,900 in the City of Antwerp, it is clear that the organization of local governments' administrations is diverse (Steen and Wayenberg, 2003). Data and information in the Region of Flanders are fragmented across 308 municipalities, the regional administration, the federal administration, and the private sector. To achieve interoperability among these actors, robust, coherent, and universally applicable data standards are essential (European Commission, 2017). Since 2009, there has been a demand for Open Data standards and transparent governance (Hautekiet, 2009). The Region of Flanders has an extensive track record on information governance since 2009 which stems from its governance of geospatial data (Chantillon, Crompvoets, Peristeras, 2017). In 2012, the Flemish municipalities initiated an interoperability initiative 'Open Standards for Local Governments' (OSLO) to facilitate the re-use of information across all IS (Buyle et al., 2016). They initiated thematic working groups with participants from government, industry, and academia, agreeing on reusable data specifications to facilitate sharing and re-use of information across IS. In 2015, the steering committee for Flemish Information 
and ICT Policy was installed. The committee is empowered by decree and engages the regional government, cities, academia, and industry via a so-called Triple Helix approach (Kolehmainen et al., 2016).

\subsection{Data Standards in Smart Cities}

In Smart Cities an amalgamate set of devices is deployed to generate different types of (real-time) data. These peripheral devices are connected to IS via existing communication networks. The mapping of traffic flows is an epitome case for interoperability in smart cities. For example, the quality of service, air, and noise can be ascertained from traffic models. Without proper agreements, multiple sound meters and cameras end up being connected to the same post because their sensor data is only suitable for a specific application. An example of a widespread data standard is the data exchange standard for the transfer of traffic information (DATEX2) managed by the European Committee for Standardisation (CEN) (Badii et al., 2017). The standard was extended so as to be able to publish the availability of parking spaces within Smart Cities. DATEX2 was rewired to a Linked Data format, allowing different sensor datasets to be interlinked on a semantical level and become machinereadable (Colpaert, 2017). In the region of Flanders, best practices related to publishing data in an interoperable and sustainable way are ratified by the thirteen biggest Cities and the Regional Government in an Open Data Charter (Smart Flanders, 2018).

\section{Theoretical Background and Hypothesis Development}

\subsection{Acceptance Models for Data Standards}

The goal of this article is to explore the user's attitude towards data standards in the public sector as well as the factors that affect their adoption. The identification of the factors that cause people to accept new technologies has been researched heavily over the past decades (Keen, 1981; King \& He, 2006; Venkatesh, Morris, Davis, \& Davis, 2003). Acceptance models in relation to the adoption of data standards emerged in the health and e-commerce sector (Chen, 2003; Lin, Roan, \& Yeh, 2012; Pai, 2011). As e-commerce websites need to be seamlessly integrated with the back-office applications of their suppliers, who provide information on the price and availability of their products, data standards that lower the integration cost and avoid vendor lock-in are crucial. Chen (2003) researched the adoption and diffusion of standards in the context of e-business. The adoption framework builds upon Rogers' (2003) Innovation Diffusion Theory (IDT). Rogers defines innovation as "an idea, practice, or object that is perceived as new by an individual or other unit of adoption" (1983, p. 12). Chen identified the challenge of "separating individual and organizational decisions" (2002, p. 277). Also, this research shows that standards are often embedded in software components, which makes it hard to distinguish the adoption of the standards from the de-facto adoption of the tools. In the health sector, information standards are crucial to create patient-centric records and to allow their exchange between health-care providers. Lin et al. (2012) proposed a framework for evaluating the adoption of data standards in hospitals, which also builds upon the IDT. Lins' framework identified industrial competition and government involvement, system integrity, top management attitudes, technological capability of the staff, and organisation scale as influencers of the adoption of health data standards in hospitals. Pai (2011) analysed the introduction of healthcare IS. A healthcare IS is "a set of standards based on healthcare diagnosis, symptoms, cause, healthcare target and measurements" (Pai, 2011, p 651). These IS provide the hospital staff with integrated healthcare plans. This research builds upon one of the most widely accepted frameworks to predict and explain the adoption of IS: the Technology Acceptance Model (TAM; Davis, 1985). TAM asserts that perceived usefulness (PU) and perceived ease of use (PEU) have a determining impact on the intended and actual use of technology (DelAguila-Obra, Padilla-Meléndez, \& Abouseada, 2014). PU is defined as the probability to which a user believes that an IS will improve his or her job performance. PEU refers to the degree to which the eventual user foresees that the target system will be effortless (Davis, Bagozzi, \& Warshaw, 1989). Pai (2011) integrates TAM with the IS Success Model (Delone \& McLean, 2003) and analyses three interrelated dimensions that have an impact on PU and PEU: Information Quality, Service Quality, and System Quality. This study concludes that the proposed factors' dimensions have a positive influence on the use intention via the mediating constructs PU and PEU. As with Chen (2002), this research combines the impact of standards and technology. Mueller, Dittes, Ahlemann, Urbach, \& Smolnik (2015) researches the elements that influence the intention to accept and use IT standards and focuses on the individual. The study researches the acceptance using the TAM and the theory of planned behaviour (TPB; Ajzen, 1991). TPB states that "Attitudes toward the behaviour, subjective norms with respect to the behaviour, and perceived control over the behaviour are usually found to predict behavioural intentions with a high degree of accuracy" (Ajzen, 1991, p. 206). Mueller et al. (2015) discusses the moderating role of the personality of the individual. People with a high score on 'openness' are likely to adopt innovations.

\subsection{Technology Readiness and Acceptance Model}

The problem statement of this article is: cities are struggling due to the fragmentation of data and services across federal, regional, and local administrations. Our research question considers the relationship between individual characteristics of decision makers and their intention to use data standards. The insights of this 
paper are valuable for organisations and government administrations which aim to speed up the adoption of Open Standards to raise interoperability in complex ecosystems. Also, it provides valuable observations for researchers who aim to study and predict the use intention of Data Standards.

To find a predictor for the use of data standards in smart cities, we chose a deductive approach based on existing research. First, we derived the concept of a 'data standard'. Second, we gained a deeper understanding of the acceptance research stream. Mueller et al.'s (2015) research indicated that the acceptance of standards can be embedded in TAM. This shaped the idea of building upon TAM, as did Pai (2011) and Mueller et al. (2015). The innovative aspect of this study is that we research the moderating role of people's individual characteristics (Chen 2002; Mueller et al., 2015) in the context of the adoption of data standards.

As TAM was initially developed to predict technology adoption in settings where organizational objectives mandated their adoption, the model has limitations when applied to users who are freer to choose between several alternatives (Lin, Shih, \& Sher, 2007). Lin et al. (2007, p. 642) argue that "a model incorporating some individual difference variables is a necessary first step toward identifying and qualifying the psychological processes of the perceptions of a technology's value".

A model that considers individual differences is the technology readiness (TR) construct). Parasuraman defines the TR-construct as "people's propensity to embrace new technologies for accomplishing goals in life and work" (2000, p. 308). The construct addresses four sub-dimensions which predict people's technologyrelated behaviour: optimism and innovativeness, which can boost TR, and discomfort and insecurity, which may reduce it (Parasuraman, 2000).

The limitation of TAM is that it was initially designed to predict technology adoption in work environments, which makes it less applicable in contexts where the consumer has a higher autonomy (Lin et al., 2007). The user's perception of the usefulness and ease of use is determined by prior experience (Rao \& Monroe, 1988). Therefore Lin et al. (2007) broaden the applicability of TAM by augmenting it with the TR individual-specific construct into the Technology Readiness and Acceptance Model (TRAM). The findings of TRAM emphasise the impact of the user/individual characteristics and their prior experience on the use intention. Also, the impact of usefulness and ease of use dominates the decision-making process of adoption behaviour, which can explain why a high TR score does automatically result in a high adoption.

\subsection{Development of Hypothesis}

\subsubsection{Hypothesis}

In this article, we investigate the potential to use the TRAM-model (see Figure 1) to predict the use intention of data standards in Flanders. This will be done through the use of an adapted version of the TRAM-model as developed by Lin et al. (2007). This model is based on TAM (Davis et al., 1989) and TRI (Parasuraman \& Colby, 2015), see Figure 1.

Optimistic people generally expect that "good rather than bad things will happen to them" (Scheier \& Carver, 1985 , p. 219). How they approach the world will have an impact on their attitude towards risk perception and acceptance in relation to technology (Costa-Font, Mossialos, \& Rudisill, 2009). Parasuraman argued that optimism relates to "a positive view towards technology and trust that it will offer people more efficiency, flexibility and control" (2000, p. 311). Also, he concludes that this has a positive impact on TR. According to Lin et al. (2007), PU and PEU have reconciling effects between TR and the use intentions. Based on these insights, Hallikainen and Laukkanen (2016) argued that optimism has a positive influence on both the PEU and the PU of digital services in the business-to-business healthcare sector. Building upon this research, we propose the following hypothesis:

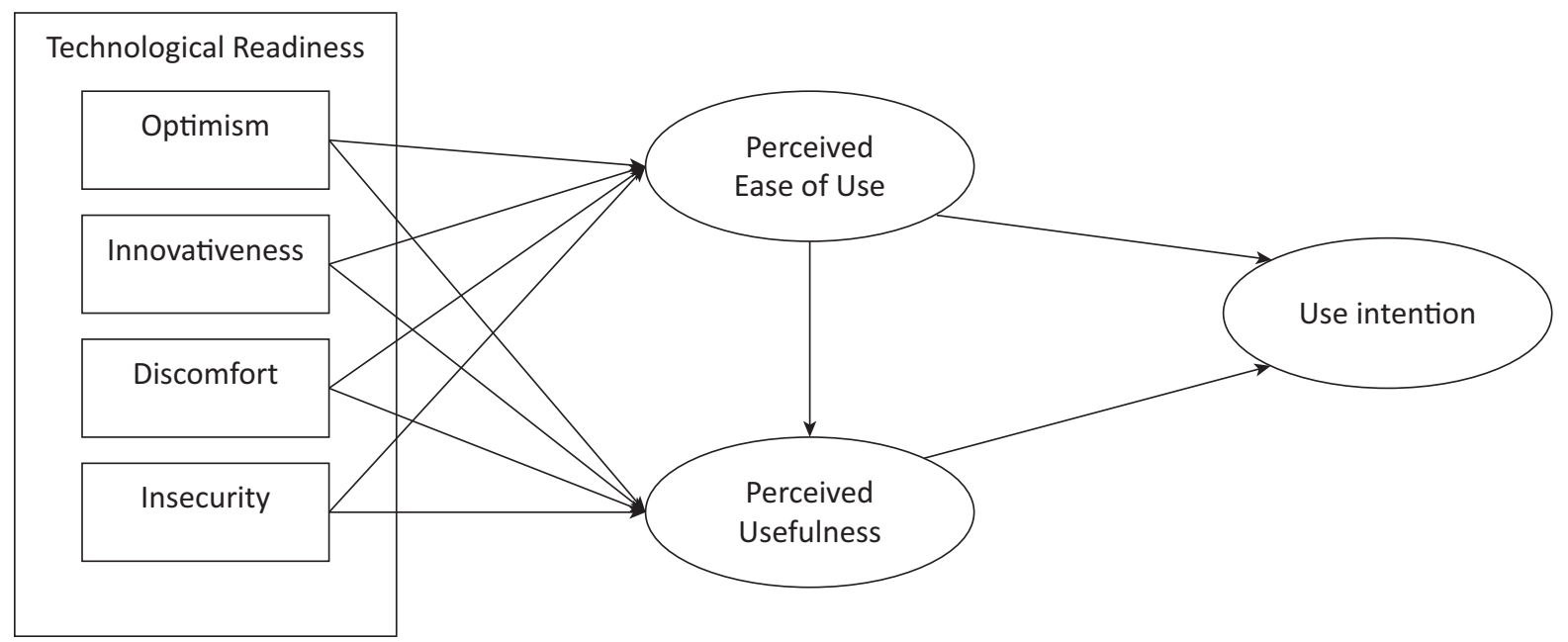

Figure 1. Theoretical model based on TRAM (Lin et al., 2007). 
- H1a: Optimism has a positive influence on perceived ease of use of data standards.

- H1b: Optimism has a positive influence on the perceived usefulness of data standards.

Garcia and Calantone (2002) state that 'innovativeness' is generally used to assess the 'newness' of an innovation, where innovative products are labelled with a high degree of newness. Users who are characterised as 'innovative' adopt new ideas earlier than others (Rogers, 2003, p. 22). Parasuraman introduces the technological dimension and refers to "a propensity of being a technology pioneer and influencer" (2000, p. 311). Venkatesh and Bala (2012) identify a direct positive link between technology readiness and the adoption of business process standards. Building upon these insights, we propose the following hypothesis:

- H2a: Innovativeness has a positive influence on perceived ease of data standards.

- H2b: Innovativeness has a positive influence on the perceived usefulness of data standards.

Discomfort attributes are defined as "a perceived lack of control regarding technology and the sense of being overwhelmed by it" (Parasuraman, 2000, p. 311). Mukherjee and Hoyer (2001) argue that the high-complexity features of technology products have a negative impact on product evaluation because of the user's learningcost. Despite the fact that both studies have hinted at there being a negative impact on the PEU and PU, some recent studies have not been able to find a correlation (Godoe \& Johansen, 2012; Walczuch, Lemmink, \& Streukens, 2007). Building upon TRAM, we propose the following hypothesis:

- H3a: Discomfort has a negative influence on perceived ease of use of data standards.

- H3b: Discomfort has a negative influence on the perceived usefulness of data standards.

Insecurity "implicates a distrust of technology and the disbelief about its ability to work properly" (Parasuraman, 2000, p. 311). Even though TRAM suggests that there is a negative impact on the PEU and PU, some recent studies have not been able to find a correlation (Godoe \& Johansen, 2012; Walczuch et al., 2007). Building upon the insights of TRAM, we propose the following hypothesis:

- H4a: Insecurity has a negative influence on perceived ease of use of data standards.

- H4b: Insecurity has a negative influence on the perceived usefulness of data standards.

Scholars have been researching the effect of PU and PEU on UI, according to the initial TAM model, reporting that PU and PEU positively influence use intention (Davis et al., 1989). However, studies on the use inten- tion of data standards are very limited, nevertheless Pai (2011) refers to a healthcare IS as a set of standards and his study demonstrates that PEU positively affects users' intention to use the IS. Therefore, we propose the following hypothesis:

- H5a: The perceived usefulness has a positive influence on the intention to use data standards.

- H5b: The perceived ease of use has a positive influence on the intention to use data standards.

There are researchers (e.g., Ramayah \& Ignatius, 2005) who have studied the relationship between perceived ease of use and perceived usefulness. In the context of data standards, both are surmised to be closely linked as the argument is such that a user who perceives data standards as "easy to use" should, in turn, develop a tendency to perceive them as useful. Therefore, we hypothesize that:

- H6: The perceived ease of use has a positive influence on perceived usefulness of data standards.

\subsubsection{Control Variable}

We have added 'the decision' maker as a control variable, by asking the respondents whether they make decisions regarding the implementation of new ICT principles. According to Mazis (1972), decision-makers are more receptive to novel information than non-decision makers.

\section{Method: Data Collection and Measurement Scales}

Data for this research was collected in June 2018 from people working in the public and private sector or as academics. An online questionnaire was developed in English and translated into Dutch. A qualitative pretest was carried out by 20 respondents. The pretest indicated that some of the questions about data standards were too conceptual. Also, the terms 'technology' and 'standards' proved to be too broad. Therefore, the questions were adjusted and definitions were added. Survey respondents were recruited using the snowball method (Biernacki \& Waldorf, 1981). This resulted in 338 responses, which after the exclusion of unfinished answers and unanswered questions provided 205 usable respondents.

The study adopts measure items of technology readiness from Parasuraman and Colby (2015) consisting of a 16-item measurement instrument evaluating an individual's propensity to adopt and use new technologies at work. The four dimensions of TRI, optimism, innovativeness, insecurity, and discomfort, consist of four measure items each. Moreover, four measure items of PEU and PU were adopted from Venkatesh and Bala (2012) (see Table 1). Use intention for data standards and decisionmaker or not are measured using manifest variables. A seven-point Likert scale ranging from " 1 = Strongly 
Table 1. The questionnaire.

\begin{tabular}{|c|c|c|}
\hline Construct & Questions & Cronbach's Alpha \\
\hline Optimism & $\begin{array}{l}\text { 1. New technologies contribute to a better quality of life. } \\
\text { 2. Technology gives me more freedom of mobility. } \\
\text { 3. Technology gives people more control over their daily lives. } \\
\text { 4. Technology makes me more productive in my personal life. }\end{array}$ & 0.800 \\
\hline Innovativeness & $\begin{array}{l}\text { 1. Other people come to me for advice on new technologies. } \\
\text { 2. In general, I am among the first in my circle of friends to acquire new } \\
\text { technology when it appears. } \\
\text { 3. I can usually figure out new high-tech products and services without help } \\
\text { from others. } \\
\text { 4. I keep up with the latest technological developments in my areas of interest. }\end{array}$ & 0.807 \\
\hline Discomfort & $\begin{array}{l}\text { 1. When I get technical support from a provider of a high-tech product or } \\
\text { service, I sometimes feel as if I am being taken advantage of by someone } \\
\text { who knows more than I do. }\end{array}$ & \\
\hline Insecurity & $\begin{array}{l}\text { 1. People are too dependent on technology to do things for them. } \\
\text { 2. Too much technology distracts people to a point that is harmful. } \\
\text { 3. Technology lowers the quality of relationships by reducing personal interaction. }\end{array}$ & 0.678 \\
\hline $\begin{array}{l}\text { Perceived ease } \\
\text { of use }\end{array}$ & $\begin{array}{l}\text { 1. Learning to work with data standards would be easy for me. } \\
\text { 2. I find it easy to work with data standards to do what I want it to do. } \\
\text { 3. It is easy for me to become skilful at using data standards. } \\
\text { 4. I find it easy to use data standards. }\end{array}$ & 0.931 \\
\hline $\begin{array}{l}\text { Perceived } \\
\text { usefulness }\end{array}$ & $\begin{array}{l}\text { 1. The use of data standards in my job enables me to accomplish tasks more } \\
\text { quickly. } \\
\text { 2. The use of data standards in my job increases my productivity. } \\
\text { 3. The use of data standards in my job makes it easier to do my job. } \\
\text { 4. The use of data standards in my job is very useful. }\end{array}$ & 0.886 \\
\hline Use intention & In the future months, I will make use of data standards in my job. & \\
\hline Decision maker & $\begin{array}{l}\text { I see myself as someone who takes decisions when it comes to purchasing } \\
\text { or implementing new ICT principles. }\end{array}$ & \\
\hline
\end{tabular}

agree" to "7 = Strongly disagree" was used for technology readiness, PEU, PU and use intention.

\section{Data Analysis and Results}

\subsection{Descriptive Statistics}

In all, 205 respondents completed the questionnaire ( $21 \%$ female and $79 \%$ male). $1 \%$ having an age of less than 24, 22\% between 25 and 34, 40\% between 35 and $44,27 \%$ between 45 and 54 , and $10 \%$ over 55 years old. Regarding the respondent's educational level, $27 \%$ have a bachelor's degree, $66 \%$ have a master's degree, $4 \%$ have a PhD degree. Just $3 \%$ only have a degree of secondary education (see Figure 2).

Regarding professional experience, $78 \%$ of the respondents are active in the public sector, $19 \%$ in the private sector and $3 \%$ in academia. From all the respondents active in the public sector; $3 \%$ are active in the Federal Government (including the federal Digital Transformation Office), 37\% in the Regional Government, $9 \%$ in the Provincial Government, $24 \%$ in the Local
Government, and 2\% in intermunicipal associations. 24\% of respondents did not provide this information (this question was not a required one) (see Figure 2).

Results show that $56 \%$ of the respondents in this sample saw themselves as a decision maker in their organisation regarding the purchase or implementation of new ICT principles or technology. $88 \%$ of our respondents working in the public sector reported that their organisation makes use of data standards.

T-tests showed no difference between gender and organisation (public, sector, academia) when it comes to making decisions. Also, we detected that people who identify themselves as a decision maker, are significantly (on the 0.05 level) more innovative, than the respondents who indicated that they are a non-decision maker.

\subsection{Validity and Reliability}

The validity of the TRAM approach was tested using convergent validity and discriminant validity. A measurement model with seven latent constructs and 26 observed variables was fit using lavaan version 0.6-2.1268 

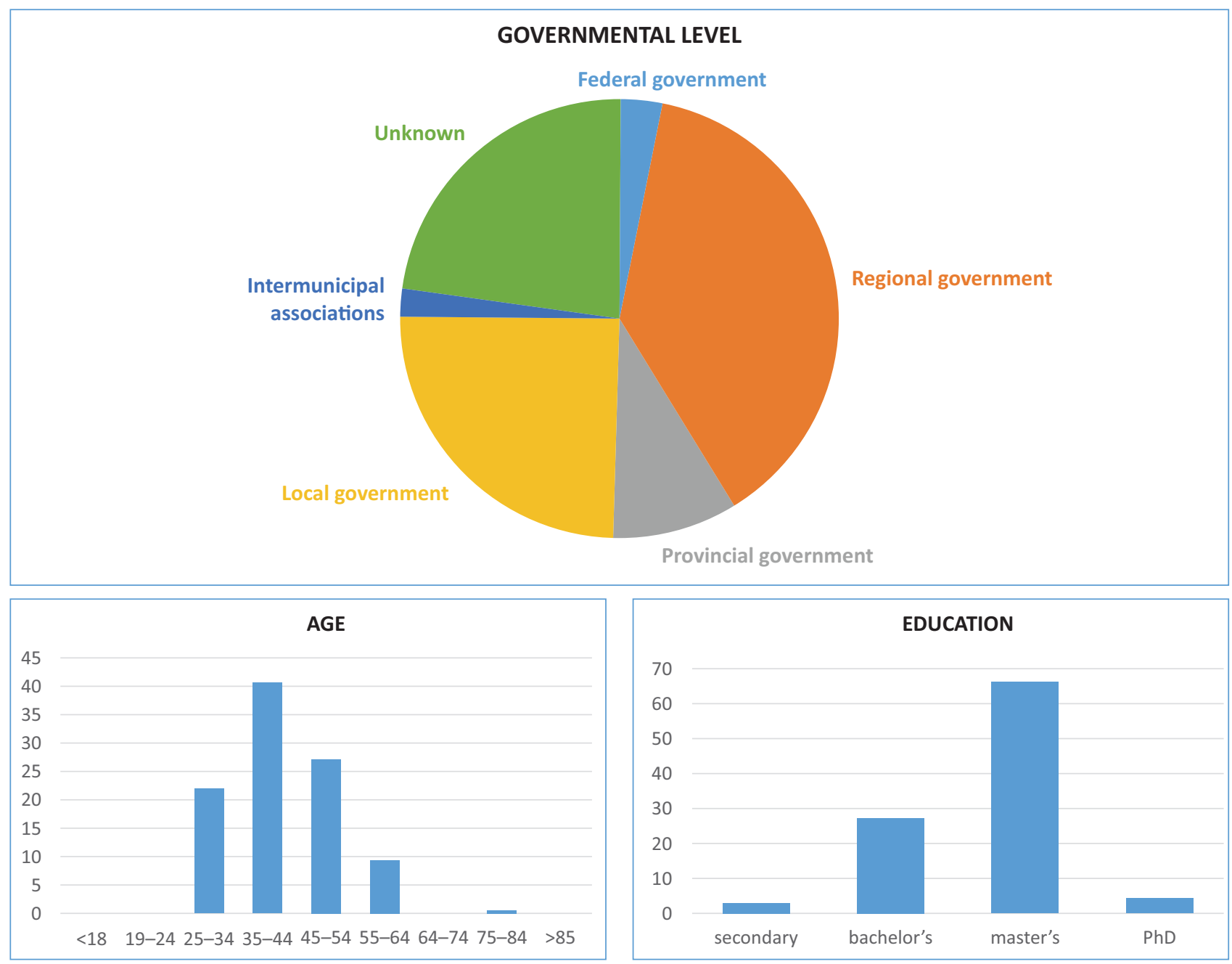

IN WHAT SECTOR ARE YOU WORKING? ( $\mathrm{N}=\mathbf{2 8 4})$

Public Sector

Private Sector

Academia

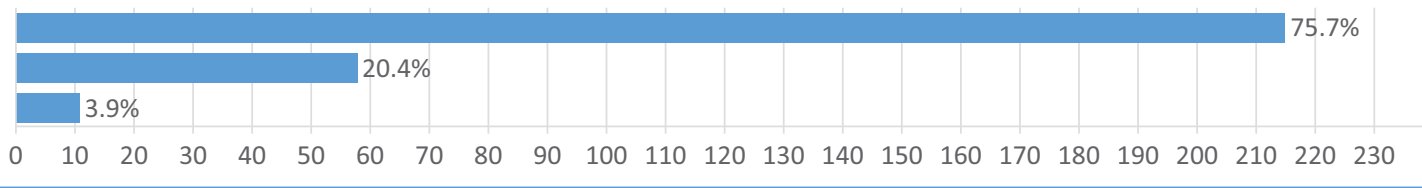

Figure 2. A sample profile of the respondents (sector, age, education and governmental level).

(Rosseel, 2012) in R version 3.4.3 (R Core Team, 2017). For the model fit assessment, we evaluated the Robust Root Mean Square Error of Approximation (RMSEA) and the Robust Comparative Fit Index (CFI). CFI should be larger than .95, RMSEA values should be .05 or lower to indicate a good fit. Small deviations from these standards are, however, acceptable (Marsh, Hau, \& Wen, 2004).

Reliability was measured based on the Cronbach's Alpha score of the constructs. As a rule of thumb, a Cronbach's Alpha ratio greater than 0.7 is considered acceptable. We can conclude that the values show acceptable reliability (see Table 1).

\subsection{Results}

The overall measurement model provides an adequate fit with $\mathrm{chi}^{2}=419.110(\mathrm{df}=259) ; \mathrm{p}<0.000, \mathrm{CFI}=0.925$ and RMSEA $=0.055$. Standardised regression loadings for all measures exceeds 0.60 except for seven items. Based on these low factor loadings (below 0.6), which indicate that the items are not valid and would, therefore, falsify results, we decided to eliminate four items for which the loadings were extremely low. Low factor loadings can be problematic because questions with low loadings do not measure the intended element. Following these modifications, the final model demonstrated an acceptable fit with $\mathrm{chi}^{2}=278.790(\mathrm{df}=174) ; p<0.000$., $\mathrm{CFI}=0.948$ and $\mathrm{RMSEA}=0.054$. Figure 2 shows the structural model.

Table 2 provides an overview of the hypothesis results. Hypothesis $\mathrm{H} 1 \mathrm{a}$ and $\mathrm{H} 1 \mathrm{~b}$ are rejected because the correlation is not statistically significant. Optimism concerns the positive attitude toward technology such as one's perceived level of control, the technology's flexi- 
Table 2. The hypothesis test results.

\begin{tabular}{|c|c|c|c|c|c|c|c|}
\hline & Hypotheses & Estimate & Std. Error & Z-values & P-values & Std. All & Decision \\
\hline $\mathrm{H} 1 \mathrm{a}$ & $\begin{array}{l}\text { Optimism } \rightarrow \text { Perceived } \\
\text { ease of use }\end{array}$ & 0.114 & 0.156 & 0.734 & 0.463 & 0.065 & Not supported \\
\hline $\mathrm{H} 1 \mathrm{~b}$ & $\begin{array}{l}\text { Optimism } \rightarrow \text { Perceived } \\
\text { usefulness }\end{array}$ & 0.109 & 0.146 & 0.748 & 0.454 & 0.062 & Not supported \\
\hline $\mathrm{H} 2 \mathrm{a}$ & $\begin{array}{l}\text { Innovativeness } \rightarrow \text { Perceived } \\
\text { ease of use }\end{array}$ & 0.397 & 0.126 & 3.147 & 0.002 & 0.287 & Supported \\
\hline $\mathrm{H} 2 \mathrm{~b}$ & $\begin{array}{l}\text { Innovativeness } \rightarrow \text { Perceived } \\
\text { usefulness }\end{array}$ & 0.297 & 0.122 & 2.440 & 0.015 & 0.216 & Supported \\
\hline $\mathrm{H} 3 \mathrm{a}$ & $\begin{array}{l}\text { Discomfort } \rightarrow \text { Perceived } \\
\text { ease of use }\end{array}$ & -0.002 & 0.067 & -0.035 & 0.972 & -0.003 & Not supported \\
\hline $\mathrm{H} 3 \mathrm{~b}$ & $\begin{array}{l}\text { Discomfort } \rightarrow \text { Perceived } \\
\text { usefulness }\end{array}$ & 0.203 & 0.063 & 3.199 & 0.001 & 0.236 & Supported \\
\hline $\mathrm{H} 4 \mathrm{a}$ & $\begin{array}{l}\text { Insecurity } \rightarrow \text { Perceived } \\
\text { ease of use }\end{array}$ & -0.154 & 0.169 & -0.908 & 0.364 & -0.081 & Not supported \\
\hline $\mathrm{H} 4 \mathrm{~b}$ & $\begin{array}{l}\text { Insecurity } \rightarrow \text { Perceived } \\
\text { usefulness }\end{array}$ & -0.317 & 0.165 & -1.924 & 0.054 & -0.169 & Not supported \\
\hline $\mathrm{H} 5 \mathrm{a}$ & $\begin{array}{l}\text { Perceived usefulness } \rightarrow \\
\text { use intention }\end{array}$ & 0.095 & 0.089 & 1.064 & 0.287 & 0.081 & Not supported \\
\hline $\mathrm{H} 5 \mathrm{~b}$ & $\begin{array}{l}\text { Perceived ease of use } \rightarrow \\
\text { use intention }\end{array}$ & 0.317 & 0.089 & 3.560 & 0.000 & 0.271 & Supported \\
\hline $\mathrm{H} 6$ & $\begin{array}{l}\text { Perceived ease of use } \rightarrow \\
\text { perceived usefulness }\end{array}$ & 0.311 & 0.074 & 4.205 & 0.000 & 0.313 & Supported \\
\hline
\end{tabular}

bility, convenience, and efficiency (Parasuraman, 2000). For people to be optimistic it is particularly essential that they are confident that the technology is under their control (Dabholkar, 1996). The results show that whether someone is a technological optimist is not related to the PEU and the PU of data standards. Other factors might be more relevant.

As expected, we obtained a positive relationship between innovativeness and both PEU and $\mathrm{PU}(\mathrm{H} 2 \mathrm{a}$ and $\mathrm{H} 2 \mathrm{~b}$ ). This highlights that innovativeness has a positive influence on perceived ease and PU of data standards. This can be explained by the fact that innovative people are more open to new ideas in general (Kwang \& Rodrigues, 2002). An individual's level of innovative attitude has been shown to be a key element in his/her acceptance of new technologies (Brancheau \& Wetherbe, 1990). Innovative individuals are eager to learn new technologies and to understand and use them which increases their technology acceptance rate (Turan, Tunc, \& Zehir, 2015). We assume that innovative people are more familiar with new technological concepts, such as data standards.

Hypothesis $\mathrm{H} 3 \mathrm{a}$ is not supported because the correlation is not statistically significant. Hypothesis $3 \mathrm{~b}$ is supported and implies that discomfort is positively correlated with PU of data standards. It implies that if people are uncomfortable with technology, they will be more likely to perceive data standards as being useful. These results are not consistent with previous literature where discomfort negatively influenced PU (Igbaria, Schiffman, \& Wieckowski, 1994). This may seem counterintuitive, however, this discomfort could lead to new solutions that mitigate the discomfort. Also, people feeling more uncomfortable with technology may have become accustomed to using existing technologies which do not meet their needs and therefore perceive data standards as useful (Kuo, Liu, \& Ma, 2013).

Hypotheses $\mathrm{H} 4 \mathrm{a}$ and $\mathrm{H} 4 \mathrm{~b}$ are both rejected because the correlation is not statistically significant. This means that there are other predictors that influence this PEU and PU of data standards (Kuo et al., 2013).

Hypothesis $\mathrm{H} 5 \mathrm{a}$ is rejected because the correlation is not statistically significant. In line with the findings of Lin et al. (2007), we see that hypothesis H5b is supported, demonstrating the positive influence of PEU on the intention to use data standards. This proves that the "userfriendliness" of data standards is associated with the use intention. Factors that contribute to higher perceived unfriendliness of data standards may be for example the conceptual or intangible characteristic of data standards or the implementation cost. Because of this high cost, (potential) users of data standards could lose focus on the advantages and the ease of use of the data standards. In other words, barriers such as cost reduce the perception of the ease of use of data standards, causing users 


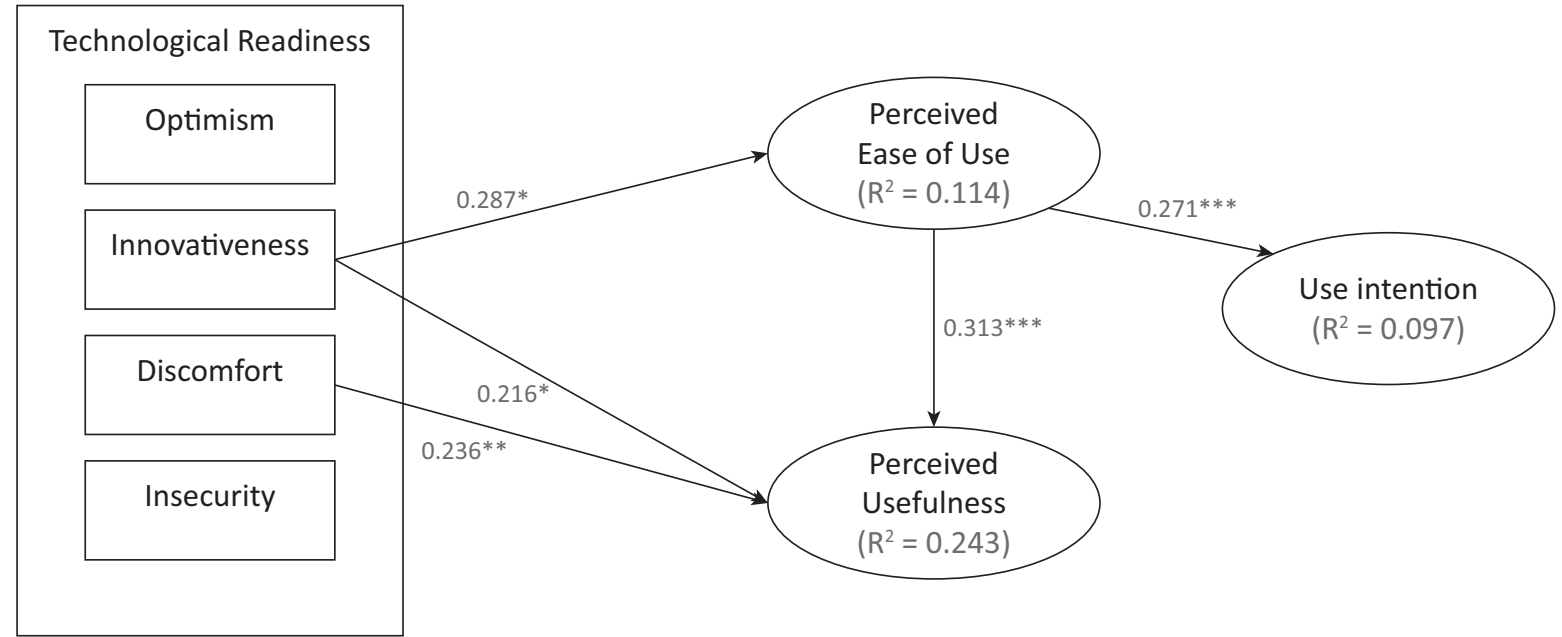

Figure 3. Structural model (standardised paths) of the total sample.

to develop a negative attitude which, in turn, leads to an unwillingness to use such data standards (Ramayah \& Ignatius, 2005).

Lastly, hypothesis $\mathrm{H} 6$ is supported. It is widely acknowledged that PEU contributes to PU (King \& He, 2006; Lin, Shih, Sher, \& Wang, 2005; Schepers \& Wetzels, 2007; Venkatesh, 2000). This is based on the theoretical argument that some user-friendly technologies could be perceived as useful, but not all useful technologies are userfriendly (Godoe \& Johansen, 2012). PU is influenced by the PEU, which means that if data standards are perceived as easy to use, they are also perceived as more useful (Kuo et al., 2013).

We can conclude that a low effect size is measured for PEU $\left(R^{2}=0.114\right)$. Figure 3 shows that PEU is driven by one determinant (innovativeness) derived from the TRAM model. Another low effect size is measured for use intention $\left(R^{2}=0.097\right)$, we see that there is only one determinant (PEU) that contributes to this construct. Finally, we see a moderate effect for PU $\left(R^{2}=0.243\right)$, predicted by innovativeness and insecurity.

\section{Discussions and Conclusion}

In this article, we investigated the potential to use the TRAM-model to predict the use intention of data standards, specifically, we looked at the relationship between individual characteristics of the decision and nondecision makers in Flanders and their intention to use data standards. This study was the first to apply the TRAM model on the use intention of data standards. Also, we applied the TRI 2.0 scale, a recently developed scale by Parasuraman \& Colby (2015). This a more recent version of the TRI 1.0, characterised by the fact that the new questionnaire is shorter and better adapted to current technological developments such as the Internet, smartphones, as well as the apps that are used on those platforms.

We detected a positive correlation between the respondent's perception of the ease of use of data stan- dards and the perceived usefulness. Also, our analysis indicates that the respondent's perceptions of data standards are positively correlated with their intention to use it. The study also indicated the positive correlation between perceived ease of use and the use intention of data standards.

This research is subject to several limitations that need to be considered. First and foremost, we saw that one characteristic of the TRAM model (innovativeness), predicts perceived ease of use and perceived usefulness of data standards within our sample of respondents. The low effect sizes show that the TRAM model is not a good fit for this context. The characteristics of our respondents indicate that they are a homogeneous group of people; active in information management with a high level of education. These different kinds of homogeneity may have biased our results as with to the study of Godoe and Johansen (2012). Moreover, creating the scores for PU and PEU was often based on a purely subjective judgement of respondents as some did not have prior experience with (implementing) data standards, as such this subjective appraisal of performance and effort does not necessarily reflect objective reality (Davis, 1989). Second, although the pretest indicated that some of the questions about data standards were too conceptual, and although the questions were adjusted and working definitions for concepts such as data standards added, respondents showed a wide diversity in interpreting the concepts that were polled, thus lessening the reliability of the results. Third, given the lack of literature on the relationship between personality traits and adoption of data standards, a more qualitative approach might have been more helpful as it would allow a more exploratory and broader research approach.

Our results indicate that respondents who score high on innovativeness have a higher intention to use data standards. According to Melas, Zampetakis, Dimopoulou and Moustakis (2011), it is essential to target these early adopters first, as they can influence their peers and the diffusion process. The diffusion process is the crucial 
stage in which "more members of the social system also adopt the same innovation" (Hoffmann, 2007, p. 87). To speed up the adoption of Open Standards and raise interoperability in complex ecosystems, we should focus on these early adopters. Our research results show that personality traits are less influential in terms of adopting data standards. Even though the TRAM-model reveals that innovativeness is an important influencer for the use intention of data standards, we expect that other parameters which are not included in the model might have an impact on the use intention such as organisational factors and potential network effects because data standardisation is a multistakeholder activity (e.g., coordination between agencies, the context of policy framework, etc.). The governance model in Flanders, with its roots in geospatial e-services and standards, can be characterised as a mix of hierarchical and network governance (Chantillon et al., 2017). Network coordination has an important impact on addressing complex problems (Provan $\&$ Kenis, 2008). Therefore, we suggest that the effects of network governance should be investigated in order to speed up the adoption of Open Standards to raise interoperability in complex ecosystems. We suggest researching the impact of organisational impediments (e.g., lack of support from top management) and economic impediments (Ouma, 2014). As Lee \& Yu (2015) suggest, raising the organisational competencies (e.g., providing user-friendly tools, training and success stories) heightens the perceived ease of use and use intention. Furthermore, our research suggests that the characteristics of the data standard (complexity, cost, relative advantage, and impact) might influence adoption (Damanpour \& Schneider, 2009).

\section{Acknowledgements}

This research was supported by the CITADEL project. This project has received funding from the European Union's Horizon 2020 research and innovation programme under grant agreement No. 726755. The authors would like to thank the team of the Open Standards for Linked Organisations programme (OSLO) for their valuable insights.

\section{Conflict of Interests}

The authors declare no conflict of interests.

\section{References}

Ajzen, I. (1991). The theory of planned behavior. Organizational Behavior and Human Decision Processes, 50(2), 179-211.

Badii, C., Bellini, P., Cenni, D., Difino, A., Nesi, P., \& Paolucci, M. (2017). Analysis and assessment of a knowledge-based smart city architecture providing service APIs. Future Generation Computer Systems, 75, 14-29.
Biernacki, P., \& Waldorf, D. (1981). Snowball sampling: Problems and techniques of chain referral sampling. Sociological Methods \& Research, 10(2), 141-163.

Brancheau, J. C., \& Wetherbe, J. C. (1990). The adoption of spreadsheet software: testing innovation diffusion theory in the context of end-user computing. Information systems research, 1(2), 115-143.

Brunsson, N., Rasche, A., \& Seidl, D. (2012). The dynamics of standardization: Three perspectives on standards in organization studies. Organization Studies, 33(5/6), 613-632.

Brynjolfsson, E., \& Kahin, B. (Eds.). (2002). Understanding the digital economy: Data, tools, and research. Cambridge, MA: MIT Press.

Buyle, R. (2017). Towards interoperability in the public sector. In Proceedings of the 16th international semantic web conference (pp. 1-8). Vienna, Austria: Springer.

Buyle, R., De Vocht, L., Van Compernolle, M., De Paepe, D., Verborgh, R., Vanlishout, Z., . . . Mannens, E. (2016). OSLO: Open standards for linked organizations. In Proceedings of the international conference on electronic governance and open society: Challenges in Eurasia (pp. 126-134). St. Petersburg, Russia. ACM.

Chantillon, M., Crompvoets, J., \& Peristeras, V. (2017). The governance landscape of geospatial e-servicesThe Belgian case. Journal of Geo-Information, 6(9), 282-307.

Chen, M. (2003). Factors affecting the adoption and diffusion of XML and Web services standards for e-business systems. International Journal of HumanComputer Studies, 58(3), 259-279.

Chesbrough, H., Vanhaverbeke, W., \& West, J. (2006). Open innovation: Researching a new paradigm. Oxford: Oxford University Press.

Colpaert, P. (2017). Publishing transport data for maximum reuse (Unpublished Doctoral dissertation). Ghent University, Belgium.

Costa-Font, J., Mossialos, E., \& Rudisill, C. (2009). Optimism and the perceptions of new risks. Journal of Risk Research, 12(1), 27-41.

Dabholkar, P. A. (1996). Consumer evaluations of new technology-based self-service options: An investigation of alternative models of service quality. International Journal of Research in Marketing, 13(1), 29-51.

Damanpour, F., \& Schneider, M. (2009). Characteristics of innovation and innovation adoption in public organizations: Assessing the role of managers. Journal of Public Administration Research and Theory, 19(3), 495-522.

Davis, F. D. (1985). A technology acceptance model for empirically testing new end-user information systems: Theory and results (Unpublished Doctoral dissertation). Massachusetts Institute of Technology, Cambridge, MA.

Davis, F. D., Bagozzi, R. P., \& Warshaw, P. R. (1989). User acceptance of computer technology: A compari- 
son of two theoretical models. Management Science, 35(8), 982-1003.

Delone, W. H., \& McLean, E. R. (2003). The DeLone and McLean model of information systems success: A tenyear update. Journal of Management Information Systems, 19(4), 9-30.

Del-Aguila-Obra, A. R., Padilla-Meléndez, A., \& Abouseada, A. (2014). Use and acceptance of social technologies by internet banking services users in the Middle East. Paper presented at XXIV congreso nacional de ACEDE, Castelló, Spain.

De Soir, E., Zech, E., Versporten, A., Van Oyen, H., Kleber, R., Mylle, J., \& van der Hart, O. (2015). Degree of exposure and peritraumatic dissociation as determinants of PTSD symptoms in the aftermath of the Ghislenghien gas explosion. Archives of Public Health, 73(1), 21.

European Commission. (2013). A vision for public services. Luxembourg: Publications Office.

European Commission. (2014). Study on eGovernment and the reduction of administrative burden. Luxembourg: Publications Office.

European Commission (2017). ISA: European Interoperability Framework (EIF). Luxembourg: Publications Office.

Farrell, J., \& Simcoe, T. (1996). Choosing the rules for formal standardization (Working Paper). Berkeley, CA: University of California.

Funk, J. L. (2001). Global competition between and within standards: The case of mobile phones. London: Palgrave Macmillan.

Garcia, R., \& Calantone, R. (2002). A critical look at technological innovation typology and innovativeness terminology: A literature review. Journal of Product Innovation Management, 19(2), 110-132.

Godoe, P., \& Johansen, T.S. (2012). Understanding adoption of new technologies: Technology readiness and technology acceptance as an integrated concept. Journal of European Psychology Students, 3(1), 38-52.

Hallikainen, H., \& Laukkanen, T. (2016). How technology readiness explains acceptance and satisfaction of digital services in B2B healthcare sector? In PACIS 2016 proceedings (pp. 294-306). New York, NY: Elsevier.

Hautekiet, P. (2009). Interbestuurlijk e-government: aandachtspunten en aanbevelingen. In B. Opsomer (Eds.), Memorandum 2009-2014-aanbevelingen voor een krachtig bestuurlijk beleid [Memorandum 2009-2014 recommendations for a strong administrative policy] (pp. 171-196). Brussels: VLABEST.

Hoffmann, V. (2007). The diffusion of innovations-The Hohenheim concept. In V. Hoffmann (Ed.), Knowledge and innovation management module reader (pp. 87-96). Hohenheim: Hohenheim University.

Igbaria, M., Schiffman, S. J., \& Wieckowski, T. J. (1994). The respective roles of perceived usefulness and perceived fun in the acceptance of microcomputer tech- nology. Behaviour \& Information Technology, 13(6), 349-361.

Keen, P. G. (1981). Information systems and organizational change. Communications of the ACM, 24(1), 24-33.

King, W. R., \& He, J. (2006). A meta-analysis of the technology acceptance model. Information \& Management, 43(6), 740-755.

Kolehmainen, J., Irvine, J., Stewart, L., Karacsonyi, Z., Szabó, T., Alarinta, J., \& Norberg, A. (2016). Quadruple helix, innovation and the knowledge-based development: Lessons from remote, rural and less-favoured regions. Journal of the Knowledge Economy, 7(1), 23-42.

Kuo, K. M., Liu, C. F., \& Ma, C. C. (2013). An investigation of the effect of nurses' technology readiness on the acceptance of mobile electronic medical record systems. BMC Medical Informatics and Decision Making, 13(1), 88-101.

Kwang, N. A., \& Rodrigues, D. (2002). A big-five personality profile of the adaptor and innovator. The Journal of Creative Behavior, 36(4), 254-268.

Lee, S., \& Yu, J. (2015). Comparative study of BIM acceptance between Korea and the United States. Journal of Construction Engineering and Management, 142(3), 1-9.

Lieberman, J., \& Ryan, A. (2017). OGC underground infrastructure concept study engineering report. Retrieved from http://www.opengis.net/doc/PER/ uicds

Lin, C. H., Lin, I. C., Roan, J. S., \& Yeh, J. S. (2012). Critical factors influencing hospitals' adoption of HL7 version 2 standards: An empirical investigation. Journal of Medical Systems, 36(3), 1183-1192.

Lin, C. H., Shih, H. Y., \& Sher, P. J. (2007). Integrating technology readiness into technology acceptance: The TRAM model. Psychology \& Marketing, 24(7), 641-657.

Lin, C. H., Shih, H. Y., Sher, P. J., \& Wang, Y. L. (2005, July). Consumer adoption of e-service: Integrating technology readiness with the technology acceptance model. In Technology management: A unifying discipline for melting the boundaries (pp. 483-488). Portland, USA: IEEE.

Marsh, H. W., Hau, K. T., \& Wen, Z. (2004). In search of golden rules: Comment on hypothesis-testing approaches to setting cutoff values for fit indexes and dangers in overgeneralizing $\mathrm{Hu}$ and Bentler's (1999) findings. Structural Equation Modeling, 11(3), 320-341.

Mazis, M. B. (1972). Decision-making role and information processing. Journal of Marketing Research, 9(4), 447-450.

Melas, C. D., Zampetakis, L. A., Dimopoulou, A., \& Moustakis, V. (2011). Modeling the acceptance of clinical information systems among hospital medical staff: An extended TAM model. Journal of Biomedical Informatics, 44(4), 553-564. 
Mills, S. (2013). International standards and the IEEE standards association in the emerging global economy. IEEE Aerospace and Electronic Systems Magazine, 28(7), 6-11.

Mueller, T., Dittes, S., Ahlemann, F., Urbach, N., \& Smolnik, S. (2015). Because everybody is different: Towards understanding the acceptance of organizational IT standards. In System sciences (HICSS), 2015 48th Hawaii international conference (pp. 4050-4058). IEEE.

Mukherjee, A., \& Hoyer, W. D. (2001). The effect of novel attributes on product evaluation. Journal of Consumer Research, 28(3), 462-472.

Nam, T., \& Pardo, T. A. (2011). Smart city as urban innovation: Focusing on management, policy, and context. In Proceedings of the 5th international conference on theory and practice of electronic governance ( $\mathrm{pp}$. 185-194).

Open Stand. (2012). Open Stand: Principles for the modern standard paradigm. Retrieved from http:// openstand.org

Ouma, F. K. (2014). Impediments to interagency statistical information sharing amongst government agencies in Uganda: A G2G adoption. In IST-Africa conference proceedings (pp. 1-11). Le Meridien Ile Maurice: IEEE.

Pai, F. Y., \& Huang, K. I. (2011). Applying the technology acceptance model to the introduction of healthcare information systems. Technological Forecasting and Social Change, 78(4), 650-660.

Parasuraman, A. (2000). Technology Readiness Index (TRI) a multiple-item scale to measure readiness to embrace new technologies. Journal of Service Research, 2(4), 307-320.

Parasuraman, A., \& Colby, C. L. (2015). An updated and streamlined technology readiness index: TRI 2.0. Journal of Service Research, 18(1), 59-74.

Provan, K. G., \& Kenis, P. (2008). Modes of network governance: Structure, management, and effectiveness. Journal of Public Administration Research and Theory, 18(2), 229-252.

Ramayah, T., \& Ignatius, J. (2005). Impact of perceived usefulness, perceived ease of use and perceived enjoyment on intention to shop online. Journal of Systems Management, 3(3), 36-51.

Rao, A. R., \& Monroe, K. B. (1988). The moderating effect of prior knowledge on cue utilization in product evaluations. Journal of Consumer Research, 15(2), 253-264.

R Core Team (2017). R: A language and environment for statistical computing. $R$ Foundation for Statistical Computing. Retrieved from https://www. R-project.org

Roe, J. W. (1916). English and American tool builders. New York and London: McGraw-Hill.

Rogers, E. M. (2003). Diffusion of innovations (5th ed.). New York, NY: Free Press.

Rosseel, Y. (2012). lavaan: An R package for structural equation modeling. Journal of Statistical Software, 48(2), 1-36.

Scheier, M. F., \& Carver, C. S. (1985). Optimism, coping, and health: Assessment and implications of generalized outcome expectancies. Health Psychology, 4(3), 219-247.

Schepers, J., \& Wetzels, M. (2007). A meta-analysis of the technology acceptance model: Investigating subjective norm and moderation effects. Information \& Management, 44(1), 90-103.

Sheridan, J. (2010). The nuts and bolts of opening government data. Digital Content Quarterly, 4(2), 6-7. Retrieved from https://sca.jiscinvolve.org/wp/ files/2010/04/sca_dcquarterly_02_apr10-final.pdf

Simcoe, T. (2006). Open standards and intellectual property rights. Open innovation: Researching a new paradigm. In H. Chesbrough, W. Vanhaverbeke, \& J. West (Eds.), Open innovation: Researching a new paradigm (pp. 161-183). Oxford: Oxford University Press.

Smart Flanders. (2018). Open data charter: 20 principes. Stedenbeleid-het Agentschap Binnenlands Bestuur [Open data charter: 20 principles. Urban Policy-The Agency for Domestic Governance]. Retrieved from https://smart.flanders.be/open-data-charter

Stango, V. (2004). The economics of standards wars. Review of Network Economics, 3(1). https://doi.org/ 10.1016/j.giq.2007.09.006

Steen , T., \& Wayenberg, E. (2003). Local governance in Flanders. In B. Denters, O. van Heffen, J. Huisman, \& P.-J. Klok (Eds.), The rise of interactive governance and quasi-markets (pp. 261-276). Dordrecht: Kluwer Academic Publishers.

Turan, A., Tunç, A. Ö., \& Zehir, C. (2015). A theoretical model proposal: Personal innovativeness and user involvement as antecedents of unified theory of acceptance and use of technology. In Proceedings of the 4th international conference on leadership, technology, innovation and business management (pp. 43-51). Yıldız: Elsevier.

Venkatesh, V. (2000). Determinants of perceived ease of use: Integrating control, intrinsic motivation, and emotion into the technology acceptance model. Information Systems Research, 11(4), 342-365.

Venkatesh, V., \& Bala, H. (2012). Adoption and impacts of interorganizational business process standards: Role of partnering synergy. Information Systems Research, 23(4), 1131-1157.

Venkatesh, V., Morris, M. G., Davis, G. B., \& Davis, F. D. (2003). User acceptance of information technology: Toward a unified view. MIS Quarterly, 27(3), 425-478.

Viale Pereira, G., Cunha, M. A., Lampoltshammer, T. J., Parycek, P., \& Testa, M. G. (2017). Increasing collaboration and participation in smart city governance: $A$ cross-case analysis of smart city initiatives. Information Technology for Development, 23(3), 526-553.

Vlaams Parlement (2008). Decreet houdende de ontsluit- 
ing en de uitwisseling van informatie over ondergrondse kabels en leidingen [Decree on the disclosure and exchange of information about underground cables and pipelines]. Belgisch Staatsblad, 178(135), 23945.

\section{About the Authors}

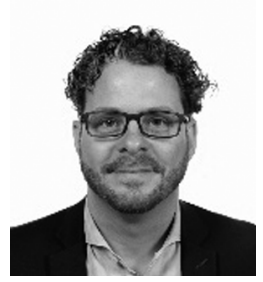

Raf Buyle is a PhD student at the Internet Technology and Data Science Lab at Ghent University. Raf has been involved in strategic e-Government projects for local and regional governments since 2002. As an Information Architect at the Flanders Information Agency, Raf tries to implement solutions for a more rational and more interoperable e-government. He is also a board member of Open Knowledge Belgium, promoting Open Data and Chairs the working group on Open Data Standards in Flanders.

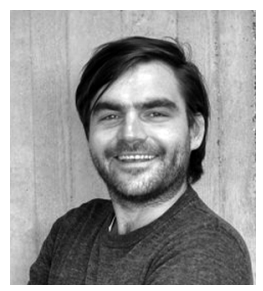

Mathias Van Compernolle joined the Research Group for Media, Innovation, and Communication Technologies at Ghent University in 2013. He holds a bachelor's degree in social work and a master's degree in Public Administration. He is currently working on his PhD concerning open data and e-government within smart cities. He functions as Policy and Methodology Lead at Smart Flanders. As an open data enthusiast at the board of Open Knowledge Belgium, he follows up open data policies in Belgium. Alongside this he lecturers politics and organization studies at Artevelde University College.

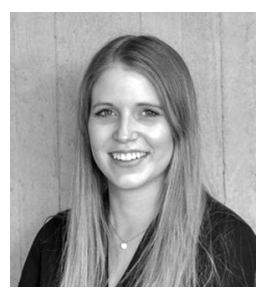

Eveline Vlassenroot holds a bachelor's degree and master's degree in Communication Sciences. Having completed additional courses in Information Management \& Security, she joined the Research Group for Media, Innovation, and Communication Technologies (www.mict.be) at Ghent University. She is involved in projects related to e-government and web archiving.

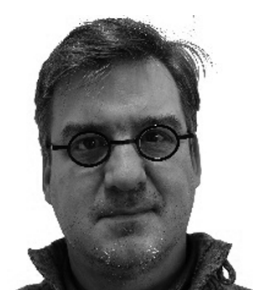

Ziggy Vanlishout has been working for the Flemish Government since 2003. For many years Ziggy was the product manager of the spatial address registry project, the Roads registry, and the buildings registry project. Today, Ziggy is the programme manager of the authentic information sources programme at the Flanders Information Agency. In the Flemish Steering Committee for Information and ICT-policy Ziggy chairs the working group on authentic data sources.

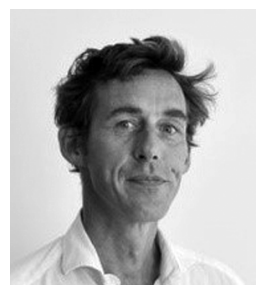

Peter Mechant is a Senior Researcher at Research Group for Media, Innovation and Communication Technologies (www.mict.be) working on projects related to e-government, smart cities, and online communities. He holds a PhD in Communication Sciences from Ghent University (2012) which focused on interactivity in a Web 2.0 context and posited a conceptual framework to explore how software enables and constrains agency and engagement.

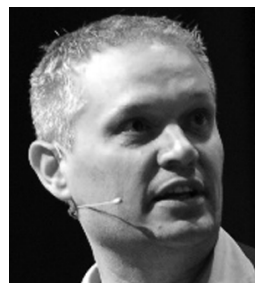

Erik Mannens as Director of valorization at Internet Technology and Data Science Lab, Erik Mannens has spent the last few years setting-up and coordinating transformational artificial intelligence projects in a wide range of industries. Furthermore, as a Semantic Intelligence Professor at Ghent University, he heads a group of 50 researchers fusing top-down semantics with bottom-up machine learning in large distributed web environments. His research interests are focused on the fusion of semantics \& machine learning, linked (open) (meta) data governance, and semantic web in general. 